\section{SOI: $1.1 / \mathrm{TAS} \quad$ DOI: $10.15863 / \mathrm{TAS}$ International Scientific Journal Theoretical \& Applied Science}

p-ISSN: 2308-4944 (print) e-ISSN: 2409-0085 (online)

Year: $2015 \quad$ Issue: $11 \quad$ Volume: 31

Published: $30.11 .2015 \quad$ http://T-Science.org
Mamathan Sharipovich Sharipov

$\mathrm{PhD}$, candidate of philosophical sciences, Docent

The "History of philosophy and logics" chair

Faculty of Social sciences

The Mirzo Ulugbek National University of Uzbekistan ilhomsharipov@mail.ru

SECTION 30. Philosophy.

\title{
THE SYNERGETICS: INTERDISCIPLINARY SYNTHESIS OF CONCEPTS
}

\begin{abstract}
In this article are discussed problems of synthesis of modern categorical knowledge in synergetics in context of interaction of philosophical and special scientific categories. Realizing such approach to problem the author coming out thinking about that the integrating role of synergetics in scientific knowledge is well visible in its basic ideas and in the maintenance of those concepts and categories with which help it develops its maintenance.

Key words: synergetics, integration of scientific knowledge's, opened systems, non linearity, self organization, dissipative structures, order, chaos, bifurcation, necessity, accident.

Language: English

Citation: Sharipov MS (2015) THE SYNERGETICS: INTERDISCIPLINARY SYNTHESIS OF CONCEPTS. ISJ Theoretical \& Applied Science 11 (31): 26-30.
\end{abstract}

Soi: http://s-o-i.org/1.1/TAS-11-31-6 Doi: crossef http://dx.doi.org/10.15863/TAS.2015.11.31.6

The synergetics (from Greek synergetikos cooperative, joint) represents arisen in the end of $\mathrm{XX}$ century and interdisciplinary direction of scientific researches intensively developing now a days. Interdisciplinary character of this new scientific direction is caused, first, by that problem which it puts before itself: revealing of the general laws operating processes of self-organizing in any systems - physical, chemical, biological, technical, social, etc. Decision of this problem assumes interaction of various spheres of scientific knowledge, their integration, association of efforts of representatives of the various sciences working in the specified direction. About it H.Hacken wrote: «I named new discipline as "synergetics" not only because in it cooperative action of many elements of system is researched but also because for a finding of the general principles operating self-organizing is necessary cooperation of many various disciplines» $[13,1]$.

As researches in new area are carried out by means of various sciences, each of which possesses the conceptual device, methods peculiar to it there are certain problems in respect of unification of concepts, reductions in harmonious system of the saved up empirical and theoretical materials. Difference in terminology and in system of the basic concepts is defined also by distinction in the approach and sights of separate scientists, schools of thought and directions and in accentuation of the various parties by them, aspects of difficult process of self-organizing.

As the new form of integration of scientific knowledge the synergetics is characterized by that «arises, leaning not on boundary, but on internal points of various sciences with which it has nonzero crossing: in studied by the $\mathrm{X}$-science (designating synergetics as «X», the author underlines circumstance that it has not developed yet as an independent science that it is in process of the formation as scientific system - M.Sh.) systems, modes and conditions of physicist, the biologist, the chemist and the mathematician see the material, and each of them, applying methods of the science, enriches the general stock of ideas and methods Xscience» $[7,99-113]$.

However, at the same time, there are also certain results in plan of interdisciplinary synthesis of scientific knowledge, their further integration, and in working out of the basic ideas, the central concepts, supervising principles of synergetics.

In given article we will concentrate the attention to the analysis of the theory of synergetics in this aspect.

It is necessary to notice that despite presence of various approaches to studied by synergetics problems are available some general ideas on which is based. According to I.Prigozhine there are open systems, nonlinearity, the self-organizing. For H.Hacken they are stability loss, parameter of an 
order and submission principle defining an essence of synergetics as a special paradigm [14, 38]. Let's remind that the paradigm in philosophy of science is understood as certain set of the standard ideas in scientific community, concepts and methods of scientific research, characteristic for this or that period of development of science. Occurrence of this new paradigm I.Prigozhine connects, first of all, with great conceptual revolution in physics of the XXth century, i.e. in its radical withdrawal pains old and creation of new concepts and representations.

The new paradigm needs to be considered, in our opinion, and as result of synthesis of scientific knowledge at various levels of their organization. For example, within a physical science such synthesis in a context of considered problem is carried out based on interaction of various physical theories.

Categorical synthesis in the synergetics theory is carried out, as it was specified above, and in the form of interdisciplinary synthesis of the knowledge which results find the reflection in creation of such specific concepts as «nonlinearity», «attractors», «bifurcation», «fractals», «determined chaos», etc. It, on the one hand, compels to reconsider existing scientific representations about formation and destruction of structures of subjects at various levels of the organization of matter, their stability and variability, convertibility and irreversibility, evolution and its direction, and with another considerably enriches the world outlook maintenance of philosophical categories of being, formation, development, system, space, time, necessity, accident, etc. and by that promote deeper integration of philosophical ideas and concepts with concrete sciences concepts and categories.

The integrating role of synergetics in scientific knowledge is well visible in its basic ideas and principles, and in the maintenance of those concepts and categories with which help it develops its maintenance.

It is necessary to underline that despite the far incomplete character, the synergetics has all bases to be considered as rather essential factor of integration of modern scientific knowledge, the factor without which account already now it is almost impossible to comprehend adequately mechanisms and forms of realization of integration processes in science, to define leading tendencies of science, to make true representation about interaction of philosophy and science, their conceptually-categorical structures in knowledge of difficult systems and processes.

We will begin with ascertaining of that the synergetics connects, synthesizes ancient nature philosophy with modern achievements of science, east ways of thinking with the western scientifically philosophical traditions. In particular, from the East the synergetics perceives and develops further idea of integrity (overall), system and idea of the general law, a uniform way - ways of Tao and from the West has inherited a support on experience and rationalism, aspiration to express scientific knowledge in mathematical language.

Addressing to consideration of question on selforganizing is necessary to mention sights of outstanding of the Central Asia thinkers of the Middle Ages, in particular, Avicenna, Abu Raikhon Biruni and Farabi. Avicenna marked: «I confirm: nature is the quality arising from interaction of opposite qualities when they stop at certain limit. These qualities exist in small particles of elements that the greatest quantity of each element has made contact with the greatest quantity of another. When they cooperate by own strength with each other, from their set there is a quality similar to them by everything that is nature» $[1,11]$. Biruni argued concerning system self-organizing as follows: «Everything that is inseparable from occurrence, there is a same occurrence. Hence, the body arises, instead of exists from time immemorial» [3, 288]. And also: « ... the features put in a being (things), and their reasons, go back to simple elements and to the beginning of their combination and creation. It is impossible to comprehend that by knowledge» [2, 268]. And Farabi so characterizes self-organizing process: «From elements are formed necessary the various mixes of certain proportions predisposed to bringing of vegetative, animal and reasonable soul from that substance which is the primary source of the world order and the spheres rotating round the steady, motionless center» $[4,24]$.

At the same time, the synergetics synthesizes also modern theories. It is, in essence, new stage of studying of the difficult systems, continuing both supplementing cybernetics and the general theory of systems. In particular, if the cybernetics takes up the issue of maintenance of stability by use of negative feedback, and the general theory of systems principles of their organization, the synergetics fixes the attention on misbalance, instability as natural state of open nonlinear systems, on plurality and ambiguity of ways of their evolution.

Speaking about communication of synergetics with scientific and philosophical tradition of the past and with modern sciences, it is necessary to underline especially that circumstance that the synergetics enters essentially new vision of the world and new understanding of evolutionary processes and ways of realization of development in this world. According to I.Prigozhine's opinion, long time «we were victims of the deformed picture of science .... For a classical science comprehended was identically unchangeable» $[11,32]$, that meant elimination of time from this scientific picture of the world. The picture of the world of the classical science based on the Laplace determinism looks from the modern point of view almost as «a caricature on evolution» $[9,16]$. 
The synergetics assumes absolutely other scientific picture in which the world acts as set of the interconnected, spontaneous processes and its intrinsic characteristics are variability, qualitative variety, misbalance and irreversibility. In this picture of the world, time gets other interpretation: it is considered the form of course of evolutionary processes, a condition of possibility of movement, change and development $[5,11]$.

According to synergetic paradigm the world is hard organizing. It is opened, i.e. is not become, but becoming, not simply existing, but continuously arising world. As underline I.Prigozhin, I.Stengers, «nowadays we enter time modern history in which being and formation can be united in consistent picture» $[10,323]$. That the deep philosophical sense of this scientific position was clear, we will compare it to the approach of classical physics to the world. Feature of the last consists in world studying in aspect of its existence in the form of certain set of the closed systems, i.e. systems isolated (not cooperating with environment neither means an exchange of energy, not the information) and equilibrium. According to the Second beginning of thermodynamics, entropy is the size characterizing a measure of disorder of system. Such approach to world knowledge, certainly, somewhat has the justification: separate parts of the Universe really can operate in the form of the closed systems, however «they at the best make only small share of the physical Universe» [10, 17]. In due time V.I.Vernadsky considered equilibrium conditions of systems and the reversible processes connected with them only as the private and passing phenomena in cyclically-irreversible development of real systems $[12,91]$. The majority of systems in the world are opened - they exchange energy and the information with environment. Biological and social systems concern number of such systems that means impossibility of an explanation of their nature within the limits of mechanical model of the world.

Therefore, «today interest is directed not on the systems which are in an equilibrium state but on that cooperating with world around through an entropy stream» $[11,33]$. The last possess unique properties. They, for example, «unite in themselves fluctuation (i.e. accident $-M$. Sh.) and stability» $[11,33]$. Open systems evolve under nonlinear laws. It means that the world is full of the unexpected turns connected with a choice of ways of the further development.

Here we will notice that nonlinearity - one of the central ideas in synergetics. It has passed to it from mathematics and designates a certain kind of the equations having some decisions in depending on the properties of environment expressed in factors. If to betray to it physical sense to set of decisions of the nonlinear equation there corresponds set of ways of evolution of the system described by these equations. Therefore nonlinearity in the philosophical, world outlook plan can be developed by means of idea of multi-variant approach of ways of evolution, of idea of a choice from alternatives and following from here of idea of irreversibility of evolution. As some researchers mark, I.Prigozhin's studying of nonlinear area in the assumption of feasibility of hypotheses of local thermodynamics has led him to reception of some inequality of the general character named by him a universal principle of evolution and the most important thing - to important result: to a substantiation of inevitability of occurrence of instability in system, occurrences of attractor with new properties in conditions when the system leaves from a condition of equilibrium [8, 59].

One more key idea of synergetics - selfeducation. The synergetics subject, strictly speaking, is self-education mechanisms, i.e. mechanisms of spontaneous occurrence, concerning steady existence and self-damage of the macroscopical ordered structures which are taking place in such systems. The self-organizing processes take place in all spheres of being. For example, differentiation of cages in live organism and evolution process in biology, the mechanism of the market of free competition in the economy, self-regulated mechanisms (automatic systems and regulators) in the technician can be carried to number of selforganizing systems. The self-organizing systems find structures inherent them or functions starting with them at the expense from the outside of energy stream without any intervention. Cooperative processes, i.e. cooperative actions of subsystems or elements in system act as the self-education source, according to H.Hacken. I.Prigozhine and after him some representatives of thermodynamics use for this purpose the term «dissipative structures», considering that dissipation i.e. energy dispersion makes necessary condition of existence of open systems and self-organizing realization. The metabolism of system with environment appears the mechanism of dissipation: on environment is thrown out the used energy and substances, and in exchange receives new substance and energy. In other words, on environment, the disorder is deduced, and the order is got. The mechanism of formation and destruction of structures, the mechanism of transition from a chaos to an order and back don't depend on the concrete nature of elements or subsystems, they are inherent both to the world natural, and to the world of social processes. Hence, the synergetics opens the general, universal mechanisms of selforganizing. These mechanisms find its reflection in such concepts of synergetics, as disorder, the spontaneous order, dissipative structures, variety and others that have interdisciplinary character. The given concepts differently are called in separate concrete sciences, for example, as statistical structures in physics, structural stability and time fluctuation in biology, public opinion in sociology. 


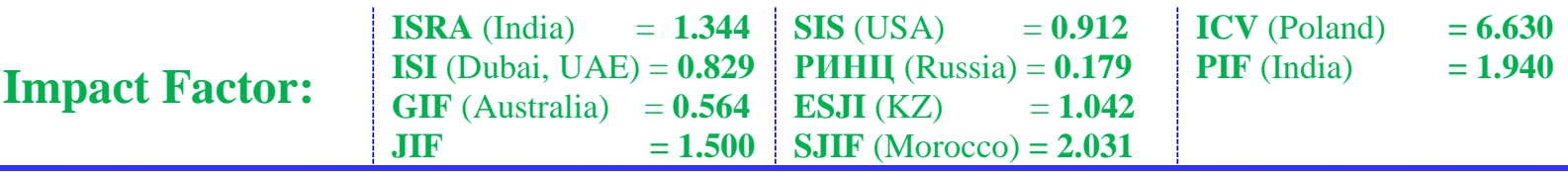

These and other disciplinary concepts are synthesized in the maintenance of the interdisciplinary concepts noted above expressing universal process of self-organizing from its various sides.

The synergetics in aspect of our studying is important still as special style of the thinking leaning on corresponding categorical structure of scientific knowledge which is result of revision of some fundamental concepts, categories of philosophy of science, such as system and element, structure and function, development and stability, space and time, necessity and accident, linearity and nonlinearity, order and chaos, probability and many other ones.

According to I.Prigozhine, «revision of the conceptual device of science conducts to new dialogue of the person with the person which ultimate goal should be more penetration into difficult mechanisms of the decision which guarantee of mechanisms of society survival. But it conducts also to new dialogue of the person with the nature» $[11,37]$.

Let's stop on the analysis of the changes which have occurred in the maintenance some of set forth above categories and we will begin with consideration of place of accident in the concept of synergetics and especially its constructive role in the course of self-organizing of difficult structures, their development and by that we will try to comprehend those changes which have occurred in an explanation of the world by means of this category and which make an essence of a modern determinism.

The science knows for a long time that any development is accompanied by a huge background of accidents. Everyone natural as underlines I.Prigozhine, «by all means contains elements of accident and necessity» [10, 50]. Accidents (in synergetics language - fluctuation, i.e. casual deviations of instant means from their average means) have weak influence incommensurable to main current don't affect, forgotten, don't define dynamics of expansion of process. Therefore the question on, whether will be possible to accident to become essential, to break from small scale in system scale as a whole, for a long time has appeared a subject of fierce disputes in philosophy of science. In philosophy, in particular in the Marxist philosophy the opinion that accident doesn't play some an appreciable role in creation of the new has prevailed. The Laplace determinism actually denied the role of accident in the course of change, developments of subjects and the world phenomena.

Now, the determinism concept was considerably enriched with the maintenance, developed in direction of recognition of coexistence accidental and necessary, connected among themselves by the relation «equal in rights partnership in the Universe, at the same time organizing and disorganizing itself» $[10,29]$. «The equal in rights partnership» finds its expression in participation of accident in occurrence of new structures, and consequently, in formation of the necessary.

Essentially new understanding of accident which follows from results of research in the field of synergetics, is reduced to the following. The accident is the creative beginning, it builds the world. She is capable to play a role «that force which deduces system on attractor, on one of own structures of environment, on an internal tendency of its organization. The nonlinear environment (system) will start to build itself, organize, but the chaos (accidents) is necessary for initiation of the initial trigger mechanism of its process» $[6,20-21]$.

The same changes have occurred also in the maintenance of other categories that have found the reflection in introduction of specific concepts of synergetics, making its scientific language. It is language of such concepts as attractors and bifurcation, fractals and the determined chaos, nonlinearity, misbalance.

The above marked moments give the grounds to draw a conclusion that synergetics, promoting integration of modern scientific knowledge, on the one hand, enriches a stock of its ideas and methods, and with another, specifies the maintenance of existing ideas and concepts of science and philosophy as a whole, enters a number of new categories into an arsenal of modern scientific thinking, showing that the special role in strengthening of relations between philosophy and science, and, first of all between their conceptual devices.

\section{References:}

1. Abu Ali Ibn Sino (1954) Kanon vrachebnoy nauki. Kniga 1. - Moscow, 1954. - 324 p.
2. Abu Raykhon Biruni (1957) Izbrannyye proizvedeniya. T. 1. Pamyatniki minuvshikh pokoleniy. - T., 1957. - 532 p. 


\begin{tabular}{|c|c|c|c|c|c|c|}
\hline Impact Factor: & $\begin{array}{l}\text { ISRA (India) } \\
\text { ISI (Dubai, UAF } \\
\text { GIF (Australia) } \\
\text { JIF }\end{array}$ & $\begin{array}{l}=1.344 \\
=0.829 \\
=0.356 \\
=1.500\end{array}$ & $\begin{array}{l}\text { SIS (USA) } \\
\text { PИНЦ (Russia) } \\
\text { ESJI (KZ) } \\
\text { SJIF (Morocco) }\end{array}$ & $\begin{array}{l}=0.912 \\
=0.179 \\
=1.042 \\
=\mathbf{2 . 0 3 1}\end{array}$ & ICV (Poland) & $=6.630$ \\
\hline
\end{tabular}

3. Abu Raykhon Biruni (1963) Izbrannyye proizvedeniya. T. 11. - T., 1963. - 485 p.

4. Al-Farabi (1972) Filosofskiye traktaty. Almaty, 1972. - 397 p.

5. Gaydenko PP (2000) Vremya i vechnost': paradoksy kontinuuma-Voprosy filosofii, 2000, №6, - 248 p.

6. Knyazeva YN (1991) Sluchaynost', kotoraya tvorit mir // V poiskakh novogo miroponimaniya: I. Prigozhin, Ye. i N. . Rerikhi.-Moscow, 1991, - 87 p.

7. Knyazeva YA (2000) Samoreflektivnaya sinergetika.-Voprosy filosofii, 2000, №4, - 256 p.

8. Kudryavtsev IK, Lebedev SA (2002) Sinergetika kak paradigma nelineynostiVoprosy filosofii, 2002, №12, - 243 p.
9. Prigozhin I (1985) Ot sushchestvuyushchego k voznikayushchemu. . Vremya i slozhnost' v fizicheskikh naukakh. -Moscow, 1985, - 227 p.

10. Prigozhin I, Stengers I (1986) Poryadok iz khaosa. -Moscow, 1986, - 432 p.

11. Prigozhin I (1991) Priroda, nauka i novaya ratsional'nost' // V poiskakh novogo miroponimaniya: I. Prigozhin, Ye. i N. . Rerikhi. -Moscow, 1991, - 104 p.

12. Simanov KV (2003) Kontseptsiya real'nogo vremeni- dleniya V.I.Vernadskogo-Voprosy filosofii, 2003, №4, - 248 p.

13. Khaken G (1980) Sinergetika. - Moscow, 1980. $-404 p$.

14. Khaken G (2000) Osnovnyye ponyatiya sinergetiki // Sinergeticheskaya paradigma. Moscow, 2000. - 232 p. 